(C) The Author(s), 2021. Published by Cambridge University Press on behalf of British Institute of International and Comparative Law. This is an Open Access article, distributed under the terms of the Creative Commons Attribution-NonCommercial-ShareAlike licence (https://creativecommons.org/ licenses/by-nc-sa/4.0/), which permits non-commercial re-use, distribution, and reproduction in any medium, provided the same Creative Commons licence is included and the original work is properly cited. The written permission of Cambridge University Press must be obtained for commercial re-use.

\title{
THE SCOPE OF STATE SOVEREIGNTY UNDER ARTICLE 194(2) TFEU AND THE EVOLUTION OF EU COMPETENCES IN THE ENERGY SECTOR
}

\author{
Kaisa Huhta*
}

\begin{abstract}
This article analyses the European Union's competences in the energy sector. It focuses on Article 194(2) of the Treaty on the Functioning of the European Union, which affords EU Member States the right to determine the conditions for exploiting their energy resources, the choice between different energy sources and the general structure of their energy supply. This article traces the constitutional development of EU competences in the energy sector to demonstrate the relevance of Article 194(2) TFEU in the current constitutional, international and sectorspecific contexts of EU energy law. It analyses the recent case law of the Court of Justice of the European Union, which shows that the scope of Article 194(2) TFEU is considerably narrower in practice than its wording implies. The article concludes by evaluating the implications of this narrow interpretation on the future development of EU energy law and, in a broader context, on the reach of EU energy and climate policy.
\end{abstract}

Keywords: EU law, primary law, division of competences, EU energy law, Article 194 TFEU, international law.

\section{INTRODUCTION}

Since the 1950s, European integration has been a delicate balancing act between State sovereignty and the fundamental European Union (EU) goal of economic integration. ${ }^{1}$ The energy sector, in this respect, is no exception. Two of the three original founding treaties - the 1951 Treaty establishing the European Coal and Steel Community (ECSC) and the 1957 Treaty establishing the European Atomic Energy Community (EURATOM) - explicitly addressed energy. ${ }^{2}$

* Senior Lecturer in EU law, University of Eastern Finland, kaisa.huhta@uef.fi. The research was supported by the Academy of Finland (projects 340998 and 338645).

1 D Chryssochoou, Theorizing European Integration (Sage 2001) 26-7 and 141-2; W Reijnen et al., The Unfinished History of European Integration (Amsterdam University Press 2018) 11-16 and 209; G Davies, 'Between Market Access and Discrimination: Free Movement as a Right to Fair Conditions of Competition' in P Koutrakos, J Snell and C Barnard (eds), Research Handbook on the Law of the EU's Internal Market (Edward Elgar 2017) 15-16; S Schill, 'Overcoming Absolute Primacy: Respect for National Identity under the Lisbon Treaty’ (2011) 48(5) CMLRev 1417-53.

2 Treaty establishing the European Coal and Steel Community (adopted 18 April 1951, entered into force 23 July 1952) 261 UNTS 140 (Treaty of Paris); Treaty establishing the European Atomic Energy Community (adopted 25 March 1957, entered into force 1 January 1958) 298 UNTS 169 
Yet for decades after the entry into force of the founding Treaties, the application of primary law to the energy sector was incidental ${ }^{3}$ rather than systematic and, overall, considered a politically sensitive sector to address through transnational rules. ${ }^{4}$

The development of secondary law in the energy sector has followed a similar pattern. While isolated sectoral legal instruments were adopted in the late 1960s and early $1970 \mathrm{~s},{ }^{5}$ exposing the energy sector to extensive transnational regulation was, for decades, considered unachievable. The reasons for this were both practical and political: energy markets are infrastructure-dependent, and those infrastructures had traditionally been designed and constructed nationally without cross-border connections. ${ }^{6}$ Furthermore, the importance of energy to national security meant that Member States were politically reluctant to cede decision-making powers in relation to the energy sector to the EU. ${ }^{7}$ In many respects, a reluctance towards EU involvement in the energy sector has persisted to this day. In fact, it took codified form in the Treaty of Lisbon in 2009. ${ }^{8}$

For the first time in EU history, the Treaty of Lisbon introduced an energyspecific competence and legal basis in primary law. It established energy as a sector where shared competences apply and, similarly to all other sectors of shared competences, the adoption of measures in the energy sector must follow the principles of conferral, proportionality and subsidiarity. ${ }^{9}$ Furthermore, the Treaty of Lisbon introduced an energy-specific legal basis in Article 194 of the Treaty on the Functioning of the European Union (TFEU) that has a threefold purpose. ${ }^{10}$ It establishes the objectives of EU

(Euratom Treaty); K Talus, EU Energy Law and Policy: A Critical Account (Oxford University Press 2013) 15 and 21-2.

3 Case 6-64 Costa v ENEL EU:C:1964:66.

${ }^{4}$ L Hancher, 'A Single European Energy Market-Rhetoric or Reality' (1990) 11 Energy Law Journal 217; M Rajavuori and K Huhta, 'Digitalization of Security in the Energy Sector: Evolution of EU Law and Policy' (2020) 13(4) Journal of World Energy Law \& Business 353, 362; K Talus and P Aalto, 'Competences in EU Energy Policy' in R Leal-Arcas and J Wouters (eds), Research Handbook on EU Energy Law and Policy (Edward Elgar 2017) 15; Talus (n 2$) 5$.

${ }^{5}$ Council Directive 68/414/EEC of 20 December 1968 imposing an obligation on Member States of the EEC to maintain minimum stocks of crude oil and/or petroleum products [1968] OJ L308/14 ('Minimum Oil Stocks Directive'); and Council Directive 73/238/EEC of 24 July 1973 on measures to mitigate the effects of difficulties in the supply of crude oil and petroleum products [1973] OJ L228/1.

${ }^{6} \mathrm{~K}$ Huhta, Capacity Mechanisms in EU Energy Law: Ensuring Security of Supply in the Energy Transition (Kluwer Law International 2019) 3, 222.

7 BK Sovacool (ed), The Routledge Handbook of Energy Security (Routledge 2013) 129; A Cherp and J Jewell, 'The Concept of Energy Security: Beyond the Four As' (2014) 75 Energy Policy 415.

8 Treaty of Lisbon amending the Treaty on European Union and the Treaty establishing the European Community (adopted 13 December 2007, entered into force 1 December 2009) 2702 UNTS 3.

9 Art 4 TFEU; A Biondi, 'Subsidiarity in the Courtroom' in A Biondi, P Eeckhout and S Ripley (eds), EU Law after Lisbon (Oxford University Press 2012); A von Bogdandy, 'Founding Principles' in A von Bogdandy and J Bast (eds), Principles of European Constitutional Law (rev 2nd edn, Hart Publishing 2011) 35-6; W Sauter, 'Proportionality in EU Law: A Balancing Act?' (2012) 15(2) CYELS 439-66.

${ }^{10}$ Consolidated version of the Treaty on the Functioning of the European Union [2012] OJ C326/47. 
energy policy and the procedure to be followed in adopting secondary law to achieve them, and provides an explicit delimitation of EU competences in the pursuit of these objectives. Article 194(2) TFEU states that measures taken to further the objectives of EU energy policy 'shall not affect a Member State's right to determine the conditions for exploiting its energy resources, its choice between different energy sources and the general structure of its energy supply'. ${ }^{11}$ This delimitation, and its meaning in the context of EU energy law and policy, is the focus of this article.

The competence limitation of Article 194(2) TFEU echoes the principle of permanent sovereignty over natural resources which is fundamental in international law and reflects Member States' need to maintain independent policy control over sectors with strong connections to national security. ${ }^{12}$ However, achieving the objectives of the Paris Agreement ${ }^{13}$ necessitates fundamental changes to the ways in which the EU produces and consumes energy, which will unavoidably impact States' choices as between different energy sources and the general structure of their energy supply. Against this backdrop, it is apparent that the interpretation of this prima facie technical competence provision of EU law has significant implications for the scope of the EU's internal energy and climate policy, for the achievement of its international climate commitments and, ultimately, for the reach of international climate law in Europe. Therefore, while the focus of this article is internal to the EU, its results have direct relevance beyond the EU and EU law.

When first introduced, this manifestation of the need to balance State sovereignty with EU integration in energy policy justifiably piqued the curiosity of various legal scholars. ${ }^{14}$ The competence limitation laid down in Article 194(2) TFEU has been described as a caveat ${ }^{15}$ and as giving Member States 'energy rights'. ${ }^{16}$ It has also been characterised as a form of resource nationalism, ${ }^{17}$ which generally refers to resource policy regimes that 'are

11 Art 194(2) TFEU.

12 The right to permanent sovereignty over natural resources was declared by the General Assembly of the United Nations in December 1962. M Bungenberg and S Hobe (eds), Permanent Sovereignty over Natural Resources (Springer 2015); RJ Heffron et al., 'A Treatise for Energy Law' (2018) 11(1) Journal of World Energy Law \& Business 34, 39-41.

${ }_{13}$ Paris Agreement on Climate Change (adopted 12 December 2015, entered into force 4 November 2016) (2016) 55 ILM 740 (Paris Agreement).

14 The most detailed analyses can be found in A Johnston and E van der Marel, 'Ad Lucem? Interpreting the New EU Energy Provision, and in Particular the Meaning of Article 194(2) TFEU' (2013) 22(5) EEELR 181, 183-4; K Haraldsdóttir, 'The Limits of EU Competence to Regulate Conditions for Exploitation of Energy Resources: Analysis of Article 194(2) TFEU' (2014) 23(6) EEELR 208; L Hancher and FM Salerno, 'Energy Policy after Lisbon' in P Eeckhout and S Ripley (eds), EU Law after Lisbon (Oxford Scholarship Online 2012); A Johnston and G Block, EU Energy Law (Oxford University Press 2012) 5. Some more recent articles on Article 194(2) TFEU have also been published, albeit without a legal focus. See, for instance, M Ringel and M Knodt, 'The Governance of the European Energy Union: Efficiency, Effectiveness and Acceptance of the Winter Package 2016' (2018) 112 Energy Policy 209.

15 Johnston and van der Marel (n 14) 181-99; Haraldsdóttir (n 14) 208-18.

16 Johnston and van der Marel (n 14); Haraldsdóttir (n 14). ${ }^{17}$ Haraldsdóttir (n 14). 
designed to direct economic activity in the mining and energy sectors towards politically defined national goals'. ${ }^{18}$ Yet the broad and abstract wording of the provision and the lack of concretising case law necessarily meant that the analyses involved much speculation over the meaning and interpretation of this new constitutional backbone of EU energy law. ${ }^{19}$

However, two recent developments in EU energy law offer new interpretative stances in relation to this discussion, allowing for a more nuanced and policyrelevant analysis of the content and implications of Article 194(2) TFEU. First, the role and interpretation of Article 194(2) TFEU have recently been addressed in the case law of the Court of Justice of the European Union (CJEU). ${ }^{20}$ Second, the EU has recently adopted the extensive 'Winter Package', which is the fourth package of secondary legislation for the energy sector. ${ }^{21}$ It builds on the same fundamental approach adopted in the first three energy packages of 1996, 2003 and 2009: achieving the objectives of EU energy law through competition and market integration. ${ }^{22}$ Unlike the first three packages, however, the Winter Package relies solely on Article 194 TFEU as its legal basis.

In light of these two recent developments, this article seeks to address a gap in current research by analysing the evolution of competences in the EU energy sector and, in particular, the interpretation of Article 194(2) TFEU. In order to achieve this objective, it first traces the constitutional development of EU energy law to demonstrate the role of Article 194(2) TFEU in EU law's current constitutional setting, for the Winter Package and in the context of the EU's energy and environmental policy (Section II). It then moves on to a doctrinal analysis of Article 194(2) TFEU, focusing on the CJEU's recent case law, the Winter Package and the relevance of Article 194(2) TFEU in the context of international law (Section III). Finally, the article draws conclusions on the implications of the analysis for the future of EU energy law and, in a broader context, for the reach of EU energy and climate policy (Section IV).

\section{THE CONSTITUTIONAL HISTORY OF EU ENERGY LAW}

\section{A. The Application of Primary Law to the Energy Sector}

Energy has come to hold a solid position in EU primary law. For a long time however, EU primary law was silent on matters of energy. This was despite

18 JD Wilson, 'Understanding Resource Nationalism: Economic Dynamics and Political Institutions' (2015) 21(4) Contemporary Politics 399, 399.

19 M Peeters, 'Governing Towards Renewable Energy in the EU: Competences, Instruments and Procedures' (2014) 21(1) MJ 39; Johnston and Block (n 14) 5; J-C Pielow and BJ Lewende, 'The EU Energy Policy After the Lisbon Treaty' in A Dorsman et al. (eds), Financial Aspects in Energy: A European Perspective (Springer 2011) 154.

${ }^{20}$ Most notably, Case T-356/15 Austria v Commission EU:T:2018:439; and Case C-594/18 P Austria v Commission EU:C:2020:742.

21 The Clean Energy for All Europeans was adopted in 2018-19 and includes eight new or recast legal instruments.

${ }^{22}$ Huhta (n 6) 3. 
the apparent connection between energy and the founding treaties, which directly governed nuclear and coal activities, and despite the general applicability of the 1957 Treaty establishing the European Economic Community (EEC) to all sectors. ${ }^{23}$ It has even been argued that primary EU law 'existed for decades without application to a number of national energy industries which were insulated from EU law' ${ }^{24}$ and that only in the late 1980s, 'after almost 30 years of relative neglect', ${ }^{25}$ was the Commission ready 'to promote the free movement of goods and effective competition' 26 in the energy sector. While the energy sector had not been entirely isolated from the effects of primary law, it is evident that it had been too politically loaded and nationally oriented for extensive legal involvement on the part of the EU. ${ }^{27}$

Primary EU law was first applied to the energy sector in 1964, albeit incidentally in a case that just happened to take place in the context of the energy sector. ${ }^{28}$ Other isolated case clusters followed. In the $1980 \mathrm{~s}$, the first cases on the applicability of free movement rules to the energy sector were reviewed by the CJEU. ${ }^{29}$ The Court confirmed that the Treaty rules on free movement did indeed apply to the energy sector but also that it was possible for Member States to derogate from those rules in the interests of public security. ${ }^{30}$

It was only in the 1990s that events taking place in the energy sector were reviewed under Treaty rules on competition, which had been applied to many other sectors throughout the 1970s and 1980s. ${ }^{31}$ The first cohesive body of case law in this area dates from the 1990s, which marked the end of the slow and incidental application of primary law to the energy sector that preceded it. ${ }^{32}$ Explanations vary as to why this happened when it did. ${ }^{33}$ However, since then, the energy sector has been subjected to extensive review under primary

23 Treaty establishing the European Economic Community (adopted 25 March 1957, entered into force 1 January 1958) 298 UNTS 3 (EEC Treaty).

24 Talus (n 2) 5.

25 L Hancher, 'Energy and the Environment: Striking a Balance?' (1989) 26 CMLRev 475, 475.

26 ibid.

27 T Daintith and L Hancher, 'The Management of Diversity: Community Law as an Instrument of Energy and Other Sectorial Policies' (1984) 4(1) YEL 123; Talus and Aalto (n 4) 15.

28 Case 6-64 Costa $v$ ENEL EU:C:1964:66.

29 Case 72/83 Campus Oil EU:C:1984:256; Case C-347/88 Commission v Greece EU: C:1990:470.

30 Case 72/83 Campus Oil EU:C:1984:256; K Huhta, 'Too Important to be Entrusted to Neighbours? The Dynamics of Security of Electricity Supply and Mutual Trust in EU Law' (2018) 43(6) ELRev 920.

31 P Ibáñez Colomo and A Kalintiri, 'The Evolution of EU Antitrust Policy: 1966-2017' (2020) 83(2) MLR 321.

32 See Cases C-157/94 Commission v Netherlands EU:C:1997:499; C-158/94 Commission v Italy EU:C:1997:500; C-159/94 Commission v France EU:C:1997:501; and C-160/94 Commission v Spain EU:C:1997:502. A Heritier and L Moral Soriano, 'Differentiating and Linking Politics and Adjudication - The Example of European Electricity Policy' (2002) 8(3) ELJ 363; P Cameron, Competition in Energy Markets (Oxford University Press 2001) 13 and 472-6.

33 Talus (n 2) 5 and 18. 
law, including free movement rules, ${ }^{34}$ antitrust rules ${ }^{35}$ and State aid rules. ${ }^{36} \mathrm{~A}$ similar historical narrative can be identified in the utilisation of EU legal bases to adopt secondary law, which is the focus of the next subsection.

\section{B. The Development of Legal Bases in the Energy Sector}

The same political drivers that restricted the application of primary law to the energy sector affected the adoption of secondary law on the basis of EU competences. Nevertheless, the first extensive package of sectoral legislation was adopted in 1996, ${ }^{37}$ and other, more isolated sector-specific legal instruments as early as the $1960 \mathrm{~s} .{ }^{38}$ These early measures relied on a resourceful utilisation of general legal bases, which are identified and classified below in Table 1 . This subsection dissects the core findings set out in the table and traces the timeline of legal bases utilised in the EU energy sector.

Table 1 illustrates the diversity of legal bases used to adopt secondary law in the energy sector pre-Lisbon. It shows that, until 2010, the adoption of secondary energy law hinged on legal bases that, most often, did not directly address the energy sector. It also demonstrates how the adoption of secondary law has changed to rely extensively on Article 194 TFEU. Article 194(1) states that the objectives of EU energy policy include ensuring the functioning of the energy market and security of supply as well as promoting energy efficiency, energy saving, the development of new and renewable forms of energy and the interconnection of energy networks. These objectives should be pursued '[i]n the context of the establishment and functioning of the internal market and with regard for the need to preserve and improve the environment' and in 'a spirit of solidarity between Member States' ${ }^{39}$ The pursuit of these objectives through secondary law should follow the ordinary legislative procedure. ${ }^{40}$ The timeline of EU secondary energy law, as illustrated by the Table, shows that aiming to achieve these objectives was part of EU energy law well before the Treaty of Lisbon.

The majority of pre-Lisbon legal instruments relied entirely on Article 114 TFEU for their legal basis. ${ }^{41}$ The second most frequently utilised legal basis for measures in the energy sector is Article 192 TFEU, which allows the EU

34 For example, Cases 72/83 Campus Oil EU:C:1984:256; C-347/88 Commission v Greece EU: C:1990:470; C-398/98 Commission v Greece EU:C:2001:565; and C-573/12 Alands Vindkraft EU: C:2014:2037.

35 For example, Case C-393/92 Almelo EU:C:1994:171. See also Cameron (n 32) 279-80.

36 For example, Cases C-379/98 PreussenElektra EU:C:2001:160; C-206/06 Essent Netwerk Noord and Others EU:C:2008:413.

37 Key legal instruments in this package include Directive 96/92/EC of the European Parliament and of the Council of 19 December 1996 concerning common rules for the internal market in electricity [1996] OJ L27/20; and Directive 98/30/EC of the European Parliament and of the Council of 22 June 1998 concerning common rules for the internal market in natural gas [1998] OJ L204/1. $\quad{ }_{38}$ The Minimum Oil Stocks Directive. ${ }^{39}$ Art 194 TFEU. ${ }^{40}$ ibid.

41 See instruments listed in (n 37). 
TABLE 1.

The Utilisation of Legal Bases in the EU Energy Sector ${ }^{42}$

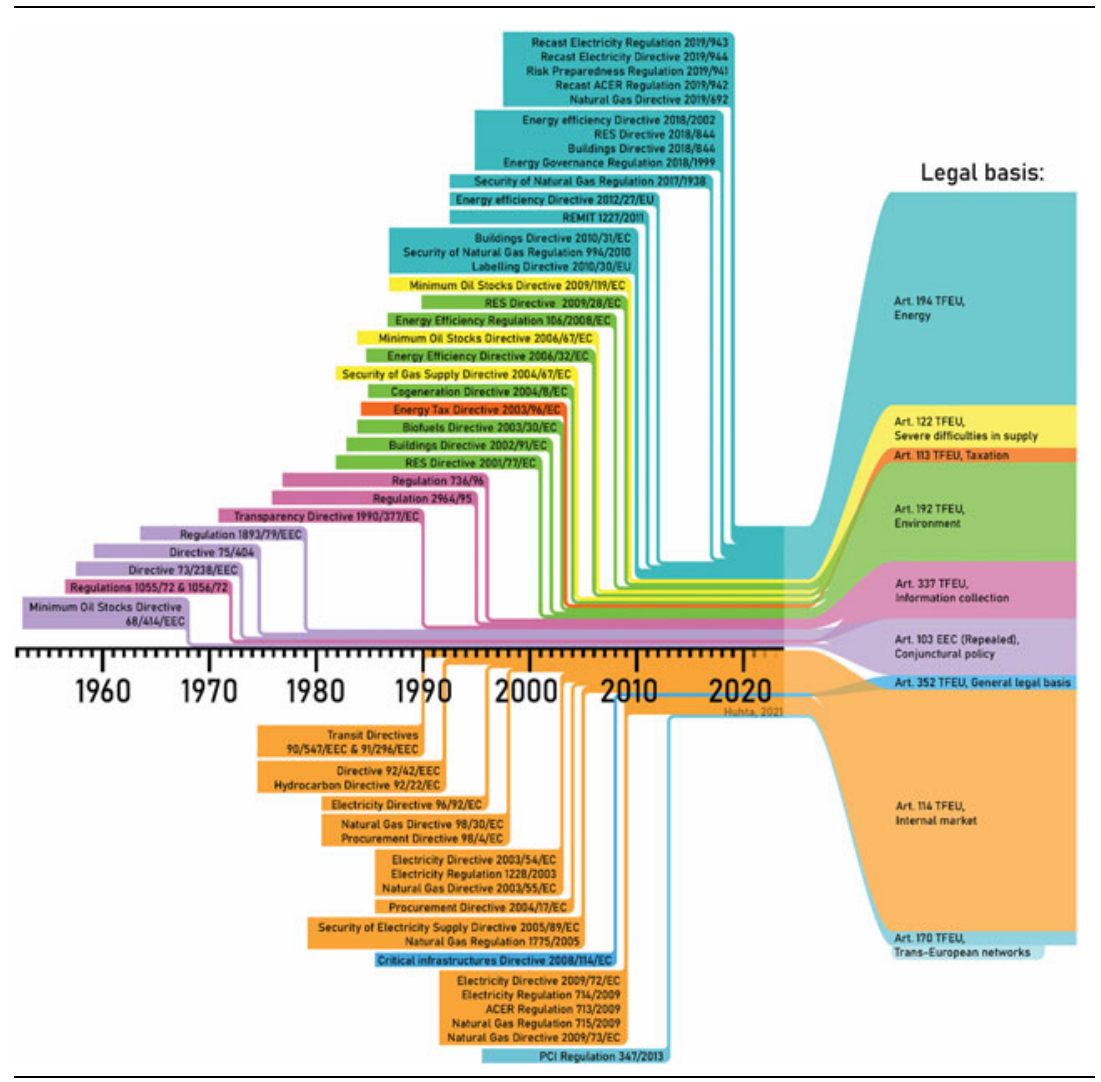

to adopt legislation in the area of environmental policy. In the energy sector, Article 192 was used as a legal basis for the adoption of directives and regulations on energy efficiency and renewable energy between 2001 and 2009.43

42 The table offers a comprehensive view of the utilisation of legal bases and the development of secondary law in the EU energy sector. However, it excludes legal instruments that apply to the energy sector but have a general scope of application, including (but not limited to) secondary law on State aid, data protection, eco-design and labelling. The table also excludes implementing and delegated acts, acts on the application of certain legal instruments, amending acts (unless significant) and secondary law that has a legal basis beyond the TFEU and its predecessors (such as EURATOM). It does not showcase dual legal bases. Finally, it excludes instruments on EU climate law, most notably rules on emissions trading, land use, land use change and forestry and effort sharing, although their relevance to the energy sector should be acknowledged. Treaty numbering of the relevant legal bases has been updated to reflect the Treaty numbering in force in 2021 .

43 The first energy-specific legal instrument adopted on the basis of Article 192 TFEU was Directive 2001/77/EC of the European Parliament and of the Council of 27 September 2001 on the promotion of electricity produced from renewable energy sources in the internal electricity 
As is true of Article 194(2) TFEU, Article 192 TFEU imposes a limitation on EU competences regarding the energy sector, albeit that, as distinct from Article 194(2), the limitation laid down in Article 192(2)(c) is more procedural in nature. To pursue the objectives of EU environmental policy, the EU should follow the ordinary legislative procedure unless so doing significantly affects 'a Member State's choice between different energy sources and the general structure of its energy supply', in which case a special legislative procedure should be followed. ${ }^{44}$ In other words, Article 192(2)(c) does not prevent the EU from legislating on issues that significantly affect a Member State's choice between different energy sources and the general structure of its energy supply, but it reserves the special legislative procedure for such issues. If there are no significant effects on Member States' energy rights, the ordinary legislative procedure applies. This is the default legislative procedure used to adopt secondary law in the EU. ${ }^{45}$ It is based on a legislative initiative by the European Commission and majority voting by the European Parliament and the Council of the European Union. ${ }^{46}$ In contrast, the special legislative procedure typically requires unanimity in the Council, which is composed of Member State ministers, and is therefore usually reserved for politically delicate subject matters.

The energy-specific delimitation of EU competences under Article 192(2)(c) TFEU shares several features with Article 194(2) TFEU. ${ }^{47}$ Both restrict EU competences when the measure affects a Member State's choice between energy sources and the general structure of its energy supply. There are, however, also clear differences. The limitation of EU competences under Article 192(2)(c) only applies if the effect on a Member State is significant. The wording of Article 194(2) does not include such a significance threshold. ${ }^{48}$ Furthermore, Article 194(2) includes a third limitation on 'a Member State's right to determine the conditions for exploiting its energy resources'. Finally, Article 192(2) allows for the adoption of EU measures despite these limitations if a special legislative procedure is followed, whereas Article 194 TFEU includes no such option.

The sector-specific legal instruments on energy efficiency and renewable energy adopted on the basis of Article 192(2) TFEU followed the ordinary legislative procedure. This is despite the fact that the 2009 Renewable

market [2001] OJ L283/33; and the last was Directive 2009/28/EC of the European Parliament and of the Council of 23 April 2009 on the promotion of the use of energy from renewable sources and amending and subsequently repealing Directives 2001/77/EC and 2003/30/EC [2009] OJ L140/16.

44 Art 192(2)(c) TFEU.

45 A Engel, The Choice of Legal Basis for Acts of the European Union: Competence Overlaps, Institutional Preferences, and Legal Basis Litigation (Springer 2018) 75-98.

46 Arts 289 and 294 TFEU.

47 On the relationship between environmental and energy policy, see R Wägenbaur and R Wainwright, 'European Community Energy and Environment Policy' (1996) 16(1) YEL 59 and H Vedder, 'The Treaty of Lisbon and European Environmental Law and Policy' (2010) 22 (2) JEL 285.

48 Johnston and van der Marel (n 14) 183-4. 
Energy Directive, for example, required Member States to alter their choice between different energy sources and the general structure of their energy supply through the obligation to increase the share of renewable energy sources in the energy mix. ${ }^{49}$ The legally binding renewable targets adopted in this directive required Member States to achieve specific shares of renewable energy in their final energy consumption by 2020 . For instance, the UK was obliged to achieve a level of 15 per cent (from 1.3 per cent in 2005) and Finland a level of 38 per cent (from 28.5 per cent in 2005). ${ }^{50}$ There seem to be no strong arguments as to why such considerable increases would not be considered significant within the meaning of Article 192(2)(c) TFEU. Nevertheless, the special legislative procedure was not used. Using the ordinary legislative procedure to adopt legal instruments that so clearly affect Member States' choice between different energy sources and the general structure of their energy supply indicates that the significance threshold laid down in Article 192(2)(c) TFEU is extremely high.

Articles 192(2)(c) and 194(2) TFEU are linked through the wording of Article 194(2), which states that the limitation of EU competences in the energy sector is 'without prejudice to Article 192(2)(c)'. This seems to indicate that if the delimitation of EU competences in Article 194(2) precludes a certain EU measure, it would be possible to adopt this measure via the special legislative procedure under Article 192, if its ambit was the pursuit of the objectives of EU environmental policy established in Article 191.51

However, settled case law on the choice of a legal basis seems to preclude using Article 192 TFEU as a legal basis for direct action in the energy sector after the adoption of Article 194 TFEU. The choice of the legal basis for an EU measure should be based on objective factors, which include the aim and content of that measure. ${ }^{52}$ If the Treaties contain several options for the adoption of an EU measure, the more specific legal basis must be chosen. ${ }^{53}$ In light of this case law, Article 194 TFEU is clearly lex specialis in relation to Article 114 TFEU in energy matters. ${ }^{54}$ By establishing the specific objectives of EU energy policy, Article 194 is also lex specialis in terms of

49 Directive 2009/28/EC of the European Parliament and of the Council of 23 April 2009 on the promotion of the use of energy from renewable sources and amending and subsequently repealing Directives 2001/77/EC and 2003/30/EC [2009] OJ L140/16.

50 Talus (n 2) 179-80.

51 M Pallemaerts, 'Climate Change, Natural Gas and the Rebirth of EU Energy Policy' in L Wylie and P Winand (eds), Energy and the Environmental Challenge: Lessons from the European Union and Australia (Peter Lang 2011) 37.

${ }_{52}$ Case C-490/10 Parliament v Council EU:C:2012:525, para 44. In terms of the choice between energy sources, see Case C-5/16 Poland v Parliament and Council EU:C:2018:483, paras 37-49; and Case C-267/11 P Commission v Latvia EU:C:2013:46, para 57.

${ }_{53}$ Cases C-490/10 Parliament $v$ Council EU:C:2012:525, para 44; C-155/07 Parliament $v$ Council EU:C:2008:605, para 34; C-300/89 Commission v Council EU:C:1991:244, para 10; C338/01 Commission v Council EU:C:2004:253, paras 54 and 60; 131/86 United Kingdom v Council EU:C:1988:86, para 29; C-91/05 Commission v Council EU:C:2008:288, para 106; and C-533/03 Commission v Council EU:C:2006:64, para 45.

54 Haraldsdóttir (n 14) 211. 
the energy sector when compared to the general environmental scope of Article 192. ${ }^{55}$ Legal instruments that combat climate change within the meaning of Article 191, for instance, would continue to be adopted using Article 192 as their legal basis even if their effects on the energy sector were immediate and considerable. However, legal instruments directly pursuing the objectives of Article 194, such as the promotion of renewable energy, would have to be adopted using Article 194 as their legal basis. In other words, it is clear that Article 194 is now the only justifiable legal basis where the direct pursuit of EU energy policy objectives is concerned.

Table 1 shows that the legal instruments adopted in the Winter Package in 2018 and 2019 all use Article 194 as their sole legal basis. Therefore, the relevance of the delimitation of Article 194(2) is now, for the first time, relevant in terms of an extensive sectoral package on energy. This interpretation was also confirmed by the CJEU in Poland $v$ Commission, in which Poland invoked Article 194(2) to annul a Commission decision, arguing that it restricted the national rights protected under Article 194(2). However, the Court rejected Poland's claim on the ground that the contested measure had been adopted on the basis of Article 192 and could, therefore, be subject to limitations laid down in that provision, but not to those laid down in Article 194(2). ${ }^{56}$ It became clear then that unless Article 194 was used as a legal basis, attempts to annul EU measures based on Article 194(2) could not succeed. The Winter Package has changed this setting altogether.

The resourceful utilisation of legal bases since the 1990s and the existence of three extensive energy-specific internal market packages even before the Treaty of Lisbon mean that the introduction of Article 194 TFEU was to some extent merely a codification of the objectives that had already underpinned EU energy law since the 1990s. ${ }^{57}$ The constitutional limitation of EU competences in the energy sector was, however, novel and its imperative wording implied fundamental restrictions on the scope of EU energy policy. Because of this and the recent developments in the EU energy sector, the interpretation of the competence limitation has become highly relevant for the EU's energy and climate policy and for achieving the EU's international climate commitments.

\section{THE INTERPRETATION OF ARTICLE 194(2) TFEU}

\section{A. Article 194(2) TFEU in the Hierarchy of Norms}

Article 194(2) TFEU forms part of EU primary law, which also includes general principles of EU law and, most relevantly from the point of view of this subsection, international law. The relevance of both public and private

\footnotetext{
55 However, see Case C-490/10 Parliament v Council ECLI:EU:C:2012:209, Opinion of the AG, paras 25 and 33-40.

56 Case T-370/11 Poland v Commission EU:T:2013:113, para 13; Haraldsdóttir (n 14) 209; Huhta (n 6) 45-6.

57 Vedder (n 47) 291.
} 
international law in the energy sector is significant. ${ }^{58}$ As a hybrid of legal disciplines, energy law frequently relies on international legal regimes on administrative law, investment and trade law and environmental law and climate law. ${ }^{59}$ The EU can enter into international agreements in situations where the Treaties provide for it or if entering into such an agreement is necessary to achieve the objectives referred to in the Treaties. ${ }^{60}$ In accordance with Article 216(2) TFEU, these international agreements are binding on the EU and its Member States. However, international law does not generally prevail over primary EU law in the event of a conflict between them. ${ }^{61}$

In the context of the interpretation of the competence limitation laid down in Article 194(2) TFEU, the scope and impact of international climate law is the most relevant, because it is underlined by the irrefutable need to change the ways in which we produce and consume energy. It is impossible to achieve change of this kind without it having a significant effect on the choices between energy sources and the structure of energy supply.

The EU is a party to the 2015 Paris Agreement, which aims to keep the global temperature increase well below $2^{\circ} \mathrm{C}$ and to pursue efforts to further limit it to $1.5^{\circ} \mathrm{C} .{ }^{62}$ Meeting this target calls for significant efforts to be made by the parties to reduce global carbon emissions. ${ }^{63}$ In the EU, the strategy to achieve this is implemented through the 2030 Climate and Energy Framework, which rests on interrelated and progressively developing legal frameworks for emissions reductions, energy efficiency and renewable energy. ${ }^{64}$ The legal framework for renewable energy requires substantial increases in the share of renewable energy sources in the overall energy mix, ${ }^{65}$ having a considerable impact upon the choice between energy sources and the general structure of Member States' energy supplies.

${ }^{58} \mathrm{~K}$ Talus, 'Internationalization of Energy Law' in K Talus (ed), Research Handbook on International Energy Law (2014) 5-7.

59 K Huhta, 'The Coming of Age of Energy Jurisprudence' (2021) 39 Journal of Energy \& Natural Resources Law 199

${ }^{60}$ Art 216 TFEU.

61 J Klabbers, Treaty Conflict and the European Union (Cambridge University Press 2009); K Ziegler, 'The Relationship between EU Law and International Law' in D Patterson and A Södersten (eds), A Companion to European Union Law and International Law (Wiley \& Sons 2016). See also Joined Cases C-402/05 P and C-415/05 P Kadi I EU:C:2008:461; Joined Cases C-584/10 P, C-593/10 P and C-595/10 P Kadi II EU:C:2013:518; and J Kokott and C Sobotta, 'The Kadi Case - Constitutional Core Values and International Law - Finding the Balance?' (2012) 23 EJIL 1015.

${ }^{62}$ Art 2 of the Paris Agreement.

${ }^{63}$ D Bodansky, 'The Legal Character of the Paris Agreement' (2016) 25(2) Review of European, Comparative \& International Environmental Law 142.

${ }^{64} \mathrm{~K}$ Kulovesi and S Oberthür, 'Assessing the EU's 2030 Climate and Energy Policy Framework: Incremental Change toward Radical Transformation?' (2020) 29(2) Review of European, Comparative \& International Environmental Law 151; K Veum and D Bauknecht, 'How to Reach the EU Renewables Target by 2030? An Analysis of the Governance Framework' (2019) 127 Energy Policy 299.

${ }^{65}$ D Gielen et al., 'The Role of Renewable Energy in the Global Energy Transformation' (2019) 24 Energy Strategy Reviews 38. 
In the EU, the Paris Agreement was entered into using Article 192 TFEU as its legal basis. ${ }^{66}$ Following the reasoning applied by the CJEU in Poland $v$ Commission discussed above, Article 194(2) TFEU can only be successfully invoked to challenge legal measures adopted on the basis of Article 194 but not on other legal bases. By analogy, this would mean that any laws adopted on the basis of Article 192 could be subject to the competence limitations laid down in Article 192 but not to those laid down in other legal bases, including Article 194(2). In the context of the Paris Agreement, this would mean that Article 194(2) could not be successfully invoked to challenge measures that are adopted to pursue the objectives of the Paris Agreement, because the Paris Agreement was adopted using Article 192 as a legal basis. This includes secondary legal measures, which have direct effects on the energy sector. Such an interpretation implies that the EU measures taken to comply with the EU's international commitments under the Paris Agreement are unlikely to be successfully challenged by Member States under Article 194(2) TFEU.

If, then, pursuing the obligations of the Paris Agreement in the EU requires Member States to change their choice between different energy sources and the general structure of their energy supply, and Article 194(2) TFEU cannot be successfully invoked to block such developments, what role is left for Article 194(2)? This role, and its political undertones, have become evident in the CJEU's recent case law, which is the focus of the next subsection.

\section{B. The Political Undertones of Article 194(2) TFEU}

The travaux préparatoires of the Treaty of Lisbon and the 2003 Draft Treaty establishing a Constitution for Europe (the Draft Constitution) are silent on the background and objective of what is now Article 194(2) TFEU.67 Parliamentary debates leading to the Draft Constitution emphasised the importance of facilitating free movement in the energy sector as a matter of priority within Europe and to increase cooperation in the energy sector. ${ }^{68}$ However, limiting EU competences in the energy sector was not discussed in the travaux préparatoires. Nevertheless, the Draft Constitution already included the core content of the limitation of EU competences in relation to energy policy, albeit that its wording differed slightly from the form it ultimately took in Article 194. It is unclear whether the delimitation was included in the Treaty at the request of a single Member State, for example, or whether it was the result of broader negotiations.

66 Paris Agreement [2016] OJ L282/4.

67 Draft Treaty establishing a Constitution for Europe [2003] OJ C169/1, art III-234 of the European Constitution. In comparison, the competence limitation laid down in Article 192 TFEU has a more substantial historical background. See Wägenbaur and Wainwright (n 47) 63.

${ }^{68}$ Minutes of the Parliament [2004] OJ C87E/405. 
Other elements of the EU's energy policy adopted with the Treaty of Lisbon included specific initiatives by single Member States. For example, the idea of pursuing the objectives of EU energy policy in 'a spirit of solidarity between Member States' was included in Article 194(1) TFEU on the insistence of Poland. ${ }^{69}$ Poland thought that both solidarity between Member States and improving the interconnection of cross-border energy networks should be enforced in the energy sector. ${ }^{70}$ It is perhaps unsurprising, therefore, that it was a case between the Commission and Poland in which the Court confirmed the principle of solidarity as being a legally binding principle of EU energy law. ${ }^{71}$

The CJEU has not taken such a forceful stance on the role of Article 194(2) TFEU as it has on the solidarity principle. However, it has clarified the interpretation of Article 194(2) in two recent cases. Again, it is perhaps unsurprising that these cases revolve around nuclear energy, a source of power that has been politically controversial in Europe since the 1970s. ${ }^{72}$ While some EU Member States rely on nuclear power extensively and consider it as an inseparable part of the low-carbon transition, others consider it an unacceptably risky means of producing electricity and have decided to phase it out entirely. ${ }^{73}$

These nuclear energy cases brought before the CJEU concerned EU State aid for nuclear power. They include the General Court case of Austria $v$ Commission and the appeal from the General Court to the European Court of Justice, which was decided as recently as September $2020 .^{74}$ The saga of these cases began in 2014, when the Commission approved the UK's planned State aid scheme for a nuclear power plant at Hinkley Point. ${ }^{75}$ To ensure future security of supply in the UK, the aid scheme comprised three aid measures: a

69 D Phinnemore, The Treaty of Lisbon: Origins and Negotiation (Palgrave Macmillan 2013) 136; J-C Pielow and BJ Lewendel, "Beyond "Lisbon": EU Competences in the Field of Energy Policy' in B Delvaux, M Hunt and K Talus (eds), EU Energy Law and Policy Issues (Intersentia 2011)

70 Phinnemore (n 69) 118, 142.

${ }^{71}$ Case T-883/16 Poland v Commission EU:T:2019:567 and case C-848/19 P Germany v Poland ECLI:EU:C:2021:598. A Boute, 'The Principle of Solidarity and the Geopolitics of Energy: Poland v. Commission (OPAL Pipeline)' (2020) 57(3) CMLRev 889; Pielow and Lewende (n 19) 153.

72 A Mignon Kirchhof and J-H Meyer, 'Global Protest against Nuclear Power. Transfer and Transnational Exchange in the 1970s and 1980s' (2014) 39(1) Historical Social Research/ Historische Sozialforschung 165.

73 L Mez, 'Nuclear energy-Any Solution for Sustainability and Climate Protection?' (2012) 48 Energy Policy 56; J Wang and S Kim, 'Comparative Analysis of Public Attitudes toward Nuclear Power Energy across 27 European Countries by Applying the Multilevel Model’ (2018) 10(5) Sustainability 1518.

${ }^{74}$ Cases T-356/15 Austria v Commission EU:T:2018:439 and C-594/18 P Austria v Commission EU:C:2020:742.

75 Commission Decision (EU) 2015/658 of 8 October 2014 on the aid measure SA.34947 (2013/C) (ex 2013/N) which the United Kingdom is planning to implement for support to the Hinkley Point C nuclear power station (notified under document C(2014) 7142) [2014] OJ L109/44. 
government-funded hedging product to stabilise the future income of the power plant; a 'Secretary of State Agreement' to protect the power plant from a politically driven shutdown of nuclear activities; and a credit guarantee by the State. ${ }^{76}$ Unprecedentedly in EU State aid law, a fellow Member State (Austria) filed for the annulment of the Commission's decision approving these aid measures, arguing that the Commission's decision was biased in favour of nuclear energy. ${ }^{77}$

In its review of the legality of the Commission's decision, the General Court held that 'the Commission did not err in finding that the United Kingdom was entitled to decide upon the promotion de [sic] nuclear energy and, more specifically, incentives for the creation of new nuclear energy generating capacity'. ${ }^{78}$ It based this argument on Article 194(2) TFEU, stating that 'it is apparent from the second subparagraph of Article 194(2) TFEU that each Member State has the right to choose between the different energy sources those they prefer' ${ }^{79}$ Furthermore, the General Court went on to confirm that '[i]n the light of the United Kingdom's right to determine its own energy mix and to maintain nuclear energy as a source in that mix ... the decision to maintain nuclear energy in the supply structure cannot be considered to be manifestly disproportionate' 80 in light of the objective of security of supply enshrined in Article 194(1) and confirmed by the CJEU. ${ }^{81}$ The UK was thus, entirely entitled to choose its emphasis as between the various energy sources available. ${ }^{82}$ The UK's choice could not be called into question even though the State funds used to support Hinkley Point were, as a result, unavailable for other projects. ${ }^{83}$ In this case, Austria's claims were dismissed on the basis that the UK measure was justifiable under Article 194(2) TFEU. ${ }^{84}$

The saga continued with Austria appealing the General Court's decision to the European Court of Justice. ${ }^{85}$ With regard to the interpretation of Article 194(2), the Court confirmed the General Court's approach. It specified that the Member States' energy rights should not be affected by measures adopted by the European Parliament and the Council and that, because of this limitation, the choice of nuclear energy is a matter for the Member States to decide. ${ }^{86}$ It confirmed that the General Court had rightly pointed out that the UK was indeed free to determine the composition of its own energy mix. ${ }^{87}$

These cases show that Article 194(2) TFEU has so far only been used as a justification in favour of Member States' support for nuclear power in the

\footnotetext{
76 L Hancher, 'State Aid to the Nuclear Power Sector: The General Court's Ruling on the UK Reactor at Hinkley Point C' (2019) 17(2) OGEL 1, 1.

77 Case T-356/15 Austria v Commission EU:T:2018:439, para 235. $\quad 78$ ibid para 97.

79 ibid.

80 ibid para 507.

81 Cases C-121/15 ANODE EU:C:2016:637, para 48; and C-411/17 Inter-Environnement Wallonie and Bond Beter Leefmilieu Vlaanderen EU:C:2019:622, para 156.

82 Case T-356/15 Austria v Commission EU:T:2018:439, para 105. $\quad 83$ ibid para 526.

${ }^{84}$ Hancher (76) $15 . \quad{ }^{85}$ Case C-594/18 P Austria v Commission EU:C:2020:742.

86 ibid paras 48-9. 87 ibid paras 79-80.
} 
interests of security of supply. No cases have been decided in which it has been used to limit the scope of measures the EU itself can take in furtherance of Article 194(1): all the cases that have been heard centre around the defence of a Member State's own measures in the energy sector. ${ }^{88}$

Advocate General Hogan's opinion in Austria v Commission underlined the political aspects of Article 194(2) TFEU and nuclear energy specifically. He characterised the dispute between Austria and the Commission as the legal side of a debate between Member States that are in favour of nuclear power and those that are not. ${ }^{89}$ In his view, Austria's argument amounted, in sum, to contending that because it is politically opposed to nuclear energy, State aid for such projects by other Member States that support nuclear energy could somehow be precluded by primary law. ${ }^{90}$ Like the General Court before him and the European Court of Justice after him, Advocate General Hogan rejected Austria's claims. He acknowledged that, on a political level, there is no consensus on the merits or perils of nuclear energy but, most importantly, that the Court has 'quite obviously neither the competence nor, just as importantly, the democratic legitimacy to rule on such issues' ${ }^{91}$ In his view, since the development of nuclear energy is an objective of primary EU law under the EURATOM Treaty, the pursuit of such an objective cannot be subordinate to other equal objectives of primary law. ${ }^{92}$ In the context of Article 194 TFEU, this argument would imply that the competence limitation in Article 194(2) TFEU could not be used to undermine the objectives of EU environmental policy, which include promoting measures at international level to deal with regional or worldwide environmental problems, and in particular combating climate change. ${ }^{93}$

What emerges from the cases and Advocate General Hogan's views is that the connection between Article 194(2) TFEU and nuclear energy seems to be more political than legal. The provision leaves Member States with a flexible margin of discretion as to how to design their energy sectors, particularly in relation to politically sensitive issues such as nuclear power. ${ }^{94}$ On the basis of these cases, however, the provision does not seem to grant Member States specific rights to opt out of EU legal measures in the energy sector or to promise Member States an EU energy policy that has no impact on their choice between different energy sources and the general structure of their energy supply. ${ }^{95}$

88 See also Case C-5/14 Kernkraftwerke Lippe-Ems EU:C:2015:354. In contrast, see Case C-80/ 18 UNESA EU:C:2019:389, Opinion of the AG, paras 36-7, where such a limitation could be inferred. However, the Court itself arrived at a different conclusion from the Advocate General.

${ }_{90}$ Case C-594/18 P Austria v Commission EU:C:2020:352, Opinion of the AG, para 1.

90 ibid para $3 . \quad 91$ ibid paras 38-43. 92 ibid para 42.

93 Art 191 TFEU. However, see ibid para 80.

94 Case C-594/18 P Austria v Commission EU:C:2020:352, Opinion of the AG, para 87.

95 As hypothesised by Johnston and van der Marel (n 14) 181. 


\section{The Threshold for Article 194(2) TFEU}

Unlike Article 192(2)(c) TFEU on environmental policy, Article 194(2) does not require that EU measures significantly affect a Member State's right to determine the conditions for exploiting its energy resources, its choice as between different energy sources and the general structure of its energy supply. In other words, the wording of Article 194(2) does not provide a threshold or a de minimis requirement for this delimitation of competences. The earlier legal scholarship on the interpretation of Article 194(2) TFEU hypothesised that such a threshold would be likely to emerge as the CJEU's case law developed. ${ }^{96}$ The reasoning for this view was that if there was no threshold the scope of EU energy policy established in Article 194(1) would be rendered extremely narrow. ${ }^{97}$

While none of the recent cases that address the interpretation of Article 194 (2) TFEU have established a threshold or a de minimis rule for this provision, the emergence of such a threshold is apparent when examining the scope of the legal instruments adopted in the Winter Package. Among other instruments, the Winter Package includes the Renewable Energy Directive ${ }^{98}$ and the Energy Union Governance Regulation. ${ }^{99}$ Together, these legal instruments oblige the Member States to achieve a minimum share of 32 per cent of energy from renewable sources in final consumption. They also include inbuilt mechanisms to review these targets should they be insufficient to achieve the EU's international obligations under the Paris Agreement. ${ }^{100}$

Achieving the objectives of the Paris Agreement and, by extension, the EU's progressively tightening climate targets, requires Member States to increase substantially their usage of renewable energy sources and, in turn, to decrease the usage of other, more carbon-intensive energy sources. This has direct effects not just on the choice as between different energy sources but also on the general structure of each Member State's energy supply. However, none of these new obligations have been challenged by Member States on the basis of Article 194 (2) TFEU. This may merely reflect the fact that Member States reached such a strong consensus on the content of the Winter Package that it did not give rise to legal disputes. More curiously, it may represent the limited practical relevance of Article 194(2), which is underlined by its character as an exception to a rule.

96 Johnston and van der Marel (n 14) 183-4.

97 Haraldsdóttir (n 14) 212.

98 Directive (EU) 2018/2001 of the European Parliament and of the Council of 11 December 2018 on the promotion of the use of energy from renewable sources [2001] OJ L328/82 ('Renewable Energy Directive').

99 Regulation (EU) 2018/1999 of the European Parliament and of the Council of 11 December 2018 on the Governance of the Energy Union and Climate Action, amending Regulations (EC) No 663/2009 and (EC) No 715/2009 of the European Parliament and of the Council, Directives 94/22/ EC, 98/70/EC, 2009/31/EC, 2009/73/EC, 2010/31/EU, 2012/27/EU and 2013/30/EU of the European Parliament and of the Council, Council Directives 2009/119/EC and (EU) 2015/652 and repealing Regulation (EU) No 525/2013 of the European Parliament and of the Council [2018] OJ L328/1.

${ }^{100}$ For instance, art 3 of the Renewable Energy Directive. 
The role of paragraph 2 as an exception to the rule is the focus of the next subsection.

\section{Article 194(2) TFEU as an Exception to the Rule}

The energy sector falls within the scope of shared competences, which means that the EU has the primary competence to legislate in the energy sector. In turn, Member States may exercise their competence only to the extent that the EU has not done so. ${ }^{101}$ The EU's primary competence, combined with the abstract and broadly worded objectives of Article 194(1) TFEU, give the EU extensive scope to adopt measures in the energy sector. In light of these facts, the delimitation laid down in Article 194(2) is a clear exception to the rule, which, according to settled case law, should be narrowly interpreted. ${ }^{102}$

This need for a narrow interpretation of an exception has been addressed with regard to the energy-specific competence limitation included in Article 192(2) (c) TFEU on environmental policy. In Poland $v$ Parliament and Council, Poland asked the Court to annul a decision establishing the market stability reserve for the EU greenhouse gas emission trading scheme. ${ }^{103}$ Poland invoked Article 192(2)(c), arguing that the decision significantly affected its choice as between different energy sources and the general structure of the country's energy supply. Poland's reasoning was that it is particularly reliant on fossil fuels and that the establishment of the market stability reserve would increase the price of emission allowances, inevitably changing the structure of the Polish energy supply. ${ }^{104}$ On the basis of this reasoning, Poland claimed that the decision had wrongfully been adopted on the basis of the ordinary legislative procedure and should, therefore, be annulled. ${ }^{105}$

Poland's claims were dismissed by both the Court and Advocate General Mengozzi. Their reasoning expanded both on the relationship between Article 191 TFEU on the objectives of EU environmental policy and on the limitations to EU competences in respect of environmental policy laid down in Article 192(2)(c). The Court held that measures taken to pursue the environmental policy objectives of Article 191 TFEU will inherently affect all Member States' energy sectors. ${ }^{106}$ In this context, a broad interpretation of

101 Art 2(2) TFEU; L Hancher and S Janssen, 'Shared Competences and Multi-Faceted Concepts - European Legal Framework for Security of Supply' in B Barton et al. (eds), Energy Security: Managing Risk in a Dynamic Legal and Regulatory Environment (Oxford University Press 2004).

102 Cases C-157/94 Commission v Netherlands EU:C:1997:499, para 37; C-159/94 Commission v France EU:C:1997:501, paras 53-5; L Hancher and P Larouche, 'The Coming of Age of EU Regulation of Network Industries and Services of General Economic Interest' in P Craig and G De Búrca, The Evolution of EU Law (Oxford University Press 2011).

103 Case C-5/16 Poland v Parliament and Council EU:C:2018:483, para 1. On the market stability reserve, see K Bruninx, M Ovaere and E Delarue, 'The Long-Term Impact of the Market Stability Reserve on the EU Emission Trading System' (2020) 89 Energy Economics 1.

104 Case C-5/16 Poland v Parliament and Council EU:C:2018:483, para 29.

105 ibid para 24.

106 ibid para 44. 
the competence limitation in Article 192(2)(c) would give Member States automatic recourse to the special legislative procedure, which is not the purpose of the competence limitation. ${ }^{107}$ The same interpretation can be analogously applied in relation to Article 194. Giving a broad interpretation to the competence limitation in paragraph 2 would render EU energy policy extremely narrow. Considering the large body of energy-specific legal instruments presented in Table 1, this has clearly not been the purpose of Article 194(2). The Court confirmed this by referring to settled case law according to which exceptions to principles should be interpreted strictly. ${ }^{108}$

The Court elaborated on its reasoning by arguing that the competence limitation of Article 192(2)(c) TFEU is relevant 'only if it follows from the aim and content of that measure that the primary outcome sought by that measure is significantly to affect a Member State's choice between different energy sources and the general structure of the energy supply of that Member State' ${ }^{109}$ As it could not be inferred that this was the aim and primary outcome of the contested market stability reserve, ${ }^{110}$ Poland could not successfully invoke the EU's competence limitation. Advocate General Mengozzi aptly posited that '[a]s a derogation, Article 192(2)(c) TFEU is to be interpreted strictly, especially since an efficient modern environment policy cannot ignore energy questions'. ${ }^{111}$

This case has direct and remarkable implications for the scope of Article 194 (2) TFEU. Applied to Article 194 analogously, the Court's ruling would mean that the EU's competence to legislate in the energy sector can only be limited by Article 194(2) in the event that the aim of the EU legal measure is to affect Member States' energy rights, its content gives effect to this and this is its primary outcome. Such a measure could be a legal instrument directly banning nuclear energy or coal, but not a legal instrument the objective of which is to promote renewable and low-carbon forms of energy production as one way of responding to the EU's obligations under international climate law. This is to say that Article 194(2) TFEU cannot be successfully invoked if the aim, content and primary outcome of the EU legal measure are not as outlined above.

\section{CONCLUDING THOUGHTS AND IMPLICATIONS FOR EU ENERGY LAW}

This article has explored the development of EU competences in the energy sector and, in particular, the interpretation of Article 194(2) TFEU as means to limit the EU's energy-specific competences. By reflecting on the constitutional development of EU energy law, the article has demonstrated how the delicate balance to be struck between Member States' resource

\footnotetext{
107 ibid para $44 . \quad 108$ ibid para 45. 109 ibid para 46.

110 Case C-5/16 Poland v Parliament and Council EU:C:2017:925, Opinion of the AG, para 25.

111 ibid para 25.
} 
sovereignty and economic integration in the energy sector has been consolidated in the architecture of the EU constitution. As the lex specialis legal basis for direct measures addressing the energy sector, Article 194 TFEU has become particularly relevant now that the Winter Package solely relies upon it for its legal basis.

Article 194(2) TFEU reflects the inclusion of the principle of permanent sovereignty over natural resources in EU energy law. ${ }^{112}$ Its wording sets out three rights that are ring-fenced against the reach of EU competences. Consequently, the wording of the provision implies an extensive limitation of EU competences in the energy sector. However, it seems that the scope of the provision is narrower in practice than its broad and imperative wording ('shall not') implies. Four reasons emerge in support of this narrow interpretation from the analysis carried out in this article. They show that the future scope of EU energy law is unlikely to reduce considerably as a result of Article 194(2).

First, the scope of Article 194(2) is necessarily limited by actions taken in the context of the EU's international obligations and its environmental policy. This was aptly underlined by Advocate General Mengozzi, who argued that an efficient modern environmental policy, including the climate objective of Article 191 TFEU, cannot ignore energy questions. ${ }^{113}$ As renewable energy, for instance, is considered to have a significant role in fulfilling the EU's international obligations under the Paris Agreement, Article 194(2) must be interpreted in the context of the EU's international commitments. If the competence limitation laid down in Article 194(2) were to be given a broad interpretation, it could severely undermine the EU's efforts under international climate law. This is unlikely to have been the legislator's intention when drafting the Treaty of Lisbon.

Second, the CJEU's recent case law indicates an increasingly narrow interpretation of the scope of Article 194(2). When first introduced, there was a great deal of uncertainty as to how this provision should be interpreted. ${ }^{114}$ While much of that uncertainty persists, recent CJEU case law and the legal instruments adopted by the EU have considerably reduced it. Two recent cases on nuclear energy, in particular, show the political nuances of Article 194(2) TFEU in disputes where there is insufficient political consensus over the choice of energy sources. This narrowing interpretation can also be inferred through analogous application of recent case law on the scope of EU competences in environmental policy. ${ }^{115}$ When applied to the EU's competences in the energy sector, this case law indicates that Article 194(2) TFEU can be successfully invoked only if the aim of the EU legal measure is to affect Member States' energy rights, its content gives effect to this and this is

112 Haraldsdóttir (n 14) 214; text and sources in (n 12).

113 Case C-5/16 Poland v Parliament and Council EU:C:2017:925, Opinion of the AG, para 25.

114 Johnston and van der Marel (n 14) 181.

115 Case C-5/16 Poland v Parliament and Council EU:C:2018:483, para 46. 
its primary outcome. Such an interpretation implies that the EU's environmental and climate policy aspirations are unlikely in practice to be compromised by the competence limitation laid down in Article 194(2) TFEU, because their aim is to address issues relating to global warming and environmental degradation, not to affect Member States' energy rights.

Third, the extensive legal instruments contained in the Winter Package seem to indicate that a threshold for the application of Article 194(2) TFEU has emerged. This is despite the fact the wording of Article 194(2) does not provide a threshold or a de minimis requirement for the delimitation of competences under it. The existing legal framework for energy in the EU cannot be enforced without considerable effects on the choice between energy sources and the energy supply structure. However, none of the new obligations contained in the Winter Package have been challenged by Member States on the basis of Article 194(2) TFEU.

Finally, Article 194(2) is an exception to the rule and, as such, should be interpreted narrowly. ${ }^{116}$ Article 194(1) lays out the objectives of EU energy law and the context in which these objectives should be pursued. This context is the internal market and the 'spirit of solidarity' between Member States, which has been confirmed as a legally binding objective of EU energy law. ${ }^{17}$ Not only are these the context of EU energy law, but Article 194(1) also explicitly establishes a functional internal market and the interconnection of energy networks as objectives of EU energy law. Both the context and these objectives underpin the importance and the primacy of EU-wide rather than national approaches and emphasise the nature of Article 194(2) as an exception to the rule of integrated rather than segregated energy solutions. 